\section{Tinjauan Kepatuhan Wajib Pajak Terkait Perlakuan, Pencatatan, dan Pelaporan PB1 dan PPH Pasal 4 ayat (1)}

\author{
Meta Melianasari Dewi dan I Wayan Teg Teg \\ Program Studi Akuntansi, Institut Bisnis dan Informatika Kesatuan, Bogor, Indonesia \\ E-Mail : meta.melianasari@ibik.ac.id
}

Tax Treatment, Registration and Reporting 255

\begin{abstract}
E-Mail : meta.melianasari@ibik.ac.id
ABSTRACT

The purpose of this study is to know and to check whether the company has carried out tax obligations by comparing the results of corporate tax reporting with the calculation of PB1 Tax and Income Tax Article 4 paragraph (2) at PT. ARP has been studied in accordance with applicable tax provisions in Indonesia. The method used in this research is analytical descriptive, researchers use primary data. Data collection techniques used by researchers are field research, interviews, documentation, and observation as well as literature studies. The study uses data management techniques, namely qualitative analysis. The results of the review show that in the process of calculation, deposit, and the reporting process of PB1 Tax and Income Tax Article 4 paragraph (2) at PT. ARP has implemented in accordance with applicable regulations. However, there are still several branch outlets within the company that have obstacles in paying taxes, from the results of the study it can be said that the company needs to pay more attention in implementing tax obligations and in the process of paying corporate taxes is expected to not exceed the deadline set in the tax regulations applicable.
\end{abstract}

Keywords: PB1, Income Tax Article 4 paragraph (2), Tax, Registration and Deposit Treatment
JIAKES

Kata Kunci: PB1, PPh Pasal 4 ayat (2), Pajak, Perlakuan Pencatatan dan Penyetoran

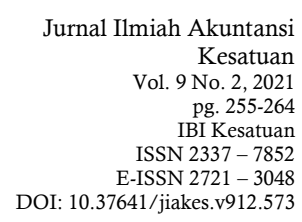


Tax Treatment, Registration and Reporting

256
PENDAHULUAN

Dalam rangka meningkatkan penerimaan yang berasal dari sektor pajak, pemerintah senantiasa membuat kebijakan dan peraturan perpajakan. Tujuannya untuk dapat menciptakan iklim usaha dan investasi yang kondusif, namun hal tersebut perlu didukung oleh kesadaran masyarakat dengan cara menjalankan kewajibannya sebagai warga Negara, yaitu dengan membayar pajak tepat waktu dan sesuai dengan peraturan yang ditetapkan. Berdasarkan data Badan Ekonomi Kreatif (Bekraf), jumlah usaha kuliner di Indonesia mencapai 5,55 juta unit atau $67,66 \%$ dari total 8,20 juta usaha ekonomi kreatif. Rata-rata pertumbuhan usaha ekonomi kreatif selama 7 tahun terakhir adalah $9,82 \%$. Tidak menutup kemungkinan usaha yang dijalankan perusahaan masih terdapat beberapa kekeliruan dalam melakukan perhitungan, penyetoran, dan pelaporan pajaknya.

Pajak adalah kontribusi wajib kepada Negara yang bersifat memaksa berdasarkan Undang-Undang dengan tidak mendapatkan imbalan secara langsung dan digunakan untuk keperluan Negara agar pemerintah dapat melaksanakan tugas-tugasnya untuk menjalankan pemerintahan. Menurut Rifky (2019) Secara presentase, pajak memberikan kontribusi yang cukup tinggi berdampak terhadap penerimaan negara mencapai sekitar 83\% dari pemerintah dalam Anggaran Pendapatan Belanja Negara (APBN). Melalui sosialisasi pajak dari berbagai media tentang dilakukannya perubahan Undang-undang Pajak Penghasilan, yaitu Undang-Undang Nomor 7 tahun 1991, Undang-Undang Nomor 10 tahun 1994, Undang-Undang Nomor 17 tahun 2000, dan terakhir adalah Undang-Undang Nomor 36 tahun 2008.

Pajak Penghasilan merupakan pajak yang dikenakan kepada orang pribadi atau bahan atas penghasilan yang diterima atau diperoleh dalam suatu tahun pajak. Dengan demikian maka penghasilan itu dapat berupa laba usaha, gaji, hadiah, bunga deposito, bonus dan lain sebagainya. Pengusaha dalam bisnis restoran sangat berpengaruh terhadap pembangunan nasional. Pajak yang terdapat dalam sebuah usaha restaurant diantaranya yaitu PB1 dan Pajak Penghasilan (PPh) Pasal 4 ayat (2).

Berdasarkan ketentuan yang ditetapkan Badan Pajak dan Retribusi Daerah Provinsi DKI Jakarta Pajak Restoran B1 adalah pajak yang dikenakan atas sajian yang diberikan. Maka biasanya dibebankan kepada konsumen yang menerima sajian dan servis dari sebuah restoran. Adapun ketentuan yang ditetapkan oleh Direktorat Jendral Pajak tentang Pajak Penghasilan Pasal 4 ayat (2), yaitu Pajak Penghasilan Pasal 4 ayat (2) mengatur pemotongan pajak atas penghasilan yang dikenakan dengan tarif dan dasar pengenaan pajak tertentu penghasilan yang diterima atau diperoleh selama tahun berjalan. PPh Pasal 4 ayat (2) langsung dibayarkan saat penghasilan diterima. Hal ini dikarenkan untuk menyederhanakan mekanisme perpajakan dan mengurangi beban administrasi wajib pajak, terutama yang masih berkembang dan belum mampu menyelenggarakan pembukuan keuangan dengan baik.

\section{METODE PENELITIAN}

Dalam penelitian ini peneliti menggunakan data primer. Teknik pengumpulan data yang digunakan peneliti adalah penelitian lapangan, pengamatan (observasi), data dari objek, data fisik proleh berdasarkan data dari objek. Penelitian ini merupakan jenis penelitian yang menggunakan metode deskriptif analitis dengan pendekatan kualitatif. Menganalisa data yang telah diperoleh melalui observasi, wawancara dan dokumentasi maka penulis menggunakan metode analisis kualitatif.

\section{HASIL DAN PEMBAHASAN}

Berdasarkan penelitian yang dilakukan peneliti pada perusahaan PT. ARP diketahui bahwa perusahaan memiliki outlet sebanyak 20 (dua puluh) outlet, penelitian ini dilakukan dalam periode 2017-2020 Februari.

\section{Perlakuan Pajak}


Perlakuan pajak yang diteliti adalah proses perhitungan PB1 dan proses perhitungan PPh pasal 4 ayat (2) yang dilakukan oleh perusahaan PT. ARP berdasarkan dokumendokumen yang diproleh dari perusahaan tersebut untuk diteliti

Proses Perhitungan PB1 - Berdasarkan Peraturan Daerah pemotongan pajaknya dikenakan sebesar $10 \%$ (sepuluh persen) dengan dasar pengenaan pajak yang dipungut oleh pemerintah daerah kabupaten/kota. Perhitungan pajak PB1 yaitu pajak bruto dikali dengan 10\% (sepuluh persen) dari pajak terutang. Berdasarkan hasil dari penellitian, diketahui data penjualan PT. ARP tahun 2017 sampai tahun 2020 bulan Februari omset penjualan PT. ARP tidak sepenuhnya data penjualan perushaan dilaporkan kepada pihak pajak, melainkan sebagian omsetnya tidak dilaporkan kepada pihak pajak. Berikut adalah rincian omset PT. ARP yang dibuat oleh tax staff yang dilaporkan kepada pihak pajak.

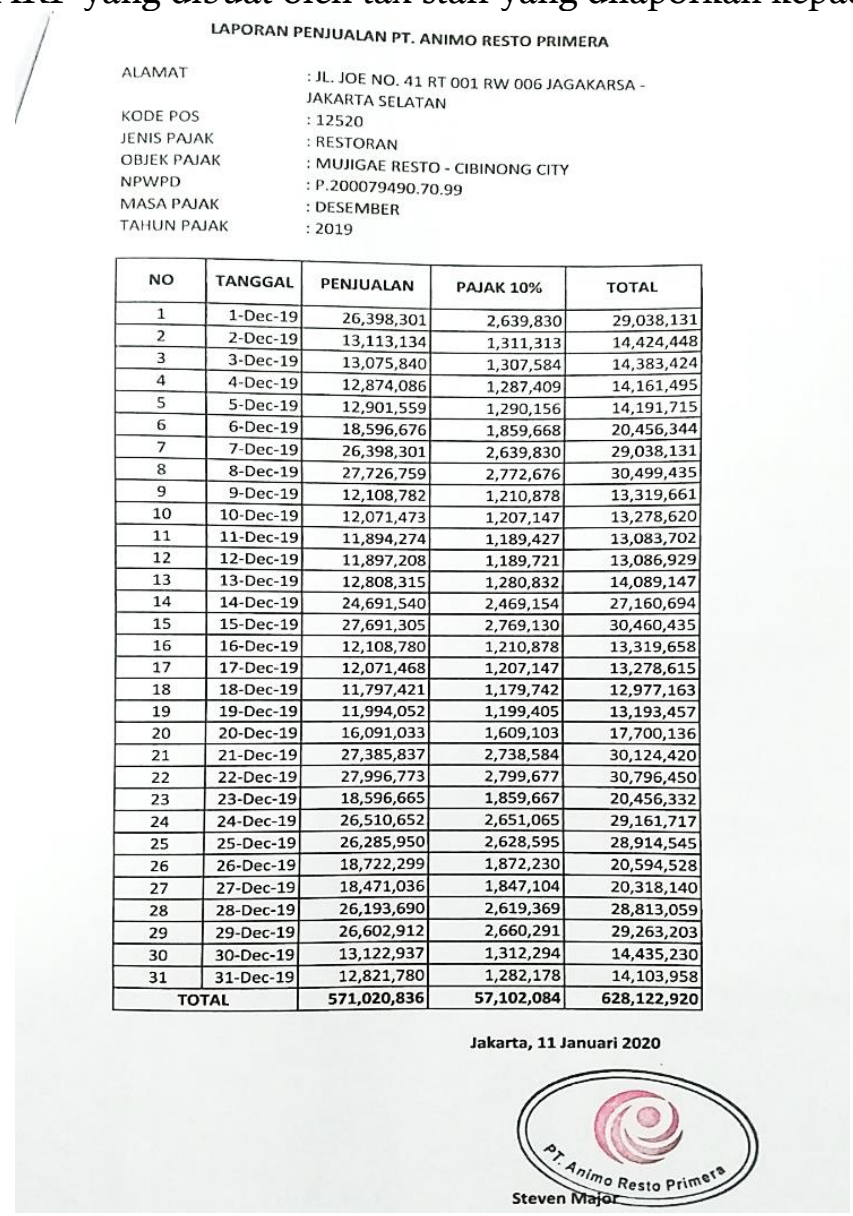

Gambar 1. Rincian Omset Penjualan PT. ARP Yang Disetor

Diketahui PT ARP dalam laporan penjualan outlet MCC memperoleh total penjualan pada suatu bulan sebesar Rp 756.010.879, akan tetapi dalam perlakuan pajaknya hanya dibayar dan dilaporkan sebesar $\mathrm{Rp}$ 628.122.920 dan nominal $\mathrm{Rp}$ 127.887.959 tidak dilaporkan. Seharusnya dalam perhitungan PB1 PT. ARP menghitung total seluruh penjualan kemudian dibagi dengan dasar pengenaan pajak sebesar 1,1 dikalikan dengan pajak restoran sebesar 10\%.

\section{Total Penjualan}

Dasar Pengenaan Pajak (Rp 756.010 .879 / 1,1)

Pajak PB1 (Rp 68.728.261 x 10\%)

$$
\begin{array}{ll}
\mathrm{Rp} & 756.010 .879 \\
\mathrm{Rp} & 687.282 .617 \\
\mathrm{Rp} & 68.728 .261
\end{array}
$$

Tax Treatment,

Registration and Reporting

Hasil dari perhitungan tersebut dapat diketahui bahwa total pajak PB1 yang dikenakan pada PT. ARP sebesar Rp 68.728.261

Proses Perhtiungan PPh Pasal 4 Ayat (2) - Dalam perhitungan pajak PPh pasal 4 ayat (2), PT. ARP adalah pemotong pajak sewa. Berdasarkan peraturan undang-undang pajak penghasilan pasal 4 ayat (2) besarnya pajak penghasilan yang dipotong sebesar $10 \%$ (sepuluh persen) baik atas penghasilan yang diterima oleh Wajib Pajak badan maupun orang pribadi dari jumlah bruto nilai persewaan tanah dan/atau bangunan. 
Tax Treatment, Registration and Reporting

\section{8}

FAKTUR PAJAK

\begin{tabular}{|c|c|c|}
\hline \multicolumn{3}{|c|}{ Kode dan Nomor Seri Faktur Pajak: xxx.xxx-xx.xxxxxxxx } \\
\hline \multicolumn{3}{|c|}{ Pengusaha Kena Pajak } \\
\hline \multicolumn{3}{|c|}{$\begin{array}{l}\text { Nama: PT. ARP } \\
\text { Alamat: } x x x x x x x x x x x x x x x x x x x x x x x x x \\
\text { NPWP: }\end{array}$} \\
\hline \multicolumn{3}{|c|}{ Pembeli Barang Kena Pajak / Penerima Jasa Kena Pajak } \\
\hline \multicolumn{3}{|c|}{$\begin{array}{l}\text { Nama: yyy } \\
\text { Alamat: yyyyyyyyyyyyyyyyyyyyyyyyy } \\
\text { NPWP: yy.yyy.yyy.y-yyy.yyy }\end{array}$} \\
\hline No. & Nama Barang Kena Pajak / Jasa Kena Pajak & $\begin{array}{c}\text { Harga Jual/Pengganti/Uang } \\
\text { Muka/Termin }\end{array}$ \\
\hline 1 & $\begin{array}{l}\text { Sewa Bangunan Mall } \\
\text { Rp } 83.739 .039 \times 1\end{array}$ & $83.739 .039,00$ \\
\hline \multicolumn{2}{|c|}{ Harga Jual / Penggantian } & $83.739 .039,00$ \\
\hline \multicolumn{2}{|c|}{ Dikurangi Potongan Harga } & 0,00 \\
\hline \multicolumn{2}{|c|}{ Dikurangi Uang Muka } & 0,00 \\
\hline \multicolumn{2}{|c|}{ Dasar Pengenaan Pajak } & $76.126 .399,00$ \\
\hline \multicolumn{2}{|c|}{ PPN $=10 \% \times$ Dasar Pengenaan Pajak } & $7.612 .639,90$ \\
\hline \multicolumn{2}{|c|}{ Total PPnBM (Pajak Penjualan Barang Mewah) } & 0,00 \\
\hline
\end{tabular}

Sesuai dengan ketentuan yang berlaku, Direktorat Jenderal Pajak mengatur bahwa Faktur Pajak ini telah ditandatangani secara elektronik sehingga tidak diperlukan tanda tangan basah pada Faktur Pajak ini.

$\operatorname{tgl}$.

Gambar 2. Faktur Pajak Penghasilan Pasal 4 Ayat (2)

Dalam faktur pajak tersebut menyatakan bahwa PT. ARP menyewa sebuah bangunan mall untuk menjalankan usahanya dan sebagai pemotong pajak sewa. Perhitungannya adalah sebagai berikut:

Harga atas Sewa Bangunan Mall Dasar Pengenaan Pajak (100/110 x 83.739.039)

$\operatorname{Rp} 83.739 .039,00$

Rp 76.126.399,00

Pajak Pertambahan Nilai (10\% x DPP)

Jumlah setor PPh Pasal 4 ayat (2) (10\% x 76.126.399)

$\mathrm{Rp} 7.612 .639,90$

$\mathrm{Rp} 7.612 .639,90$

Berdasarkan contoh faktur yang diambil menunjukan bahwa jumlah setor pajak penghasilan pasal 4 ayat (2) yang dipotong oleh perusahaan adalah sebesar $\mathrm{Rp}$ 7.612.639,90. Diketahui PT. ARP terlihat menunda pembayaran sewa sehingga pemilik bangunan mengirimkan surat peringatan ke perusahaan untuk segera mambayar biaya sewa tersebut. Dari hasil penelitian, peneliti melihat bagian AP staff dari perusahaan tersebut kurang memperhatikan pengarsipan surat-surat seperti peringatan pembayaran dan lain-lain, sehingga pemilik bangunan cenderung selalu menghubungi untuk segera melakukan proses pembayaran sewa dikarenakan surat-surat tersebut terbengkalai dan kurang tertata dengan baik.

\section{Penyetoran Pajak}

Proses Penyetoran PB1 - Setelah melakukan perhitungan pemotongan pajak restoran, selanjutnya jurnal yang seharusnya dicatat oleh PT. ARP adalah sebagai berikut:

Jurnal yang dibuat oleh PT. ARP pada saat melakukan pencatatan penjualan, yaitu:

Kas/Bank

Pendapatan Penjualan 756.010 .879

$$
\text { Utang PB1 }
$$

68.728.261 
Jurnal yang dibuat oleh PT. ARP pada saat melakukan penyetoran, yaitu:

Utang PB1 68.728.261

Kas/Bank

68.728 .261

Tax Treatment,

Registration and

Reporting

Dalam proses penyetoran PB1 PT. ARP AR staff membuat seluruh rekapan penjulan selama satu bulan, kemudian dikirmkan ke bagian tax staff, supervisor, manajer dan head of department untuk dibuat target penjualan dibulan berikutnya. Tax staff menyusun rincian omset pertanggal dimasing-masing outlet yang akan dilaporkan kepada pihak pajak melalui website pemda berupa omset perbualan yang diberikan oleh $A R$ staff ditambah dengan pajak PB1 yang harus dibayar PT. ARP. Setelah omset dilaporkan dan mendapat nomor bayar, laporan penjualan tersebut disampaikan kepada supervisor untuk menginformasikan seluruh nominal yang akan dibayarkan kepada pihak pajak, dan supervisor menyampakan ke manajer untuk memperoleh persetujuan besarnya pajak yang akan bayarkan, tax staff akan mencetak kode billing.

Proses Penyetoran PPh Pasal 4 ayat (2) - Setelah melakukan perhitungan pemotongan pajak penghasilan pasal 4 ayat (2), selanjutnya jurnal yang seharusnya dicatat oleh PT. ARP adalah sebagai berikut:

Jurnal yang dibuat oleh PT. ARP pada saat melakukan pencatatan sewa, yaitu:

\begin{tabular}{|c|cc|}
\hline Beban sewa & 83.739.039,90 & $76.126 .399,00$ \\
Kas/Bank & & \\
Htang PPh Pasal 4 Ayat (2) & $7.612 .639,90$ \\
\hline
\end{tabular}

Jurnal yang dibuat oleh PT. ARP pada saat melakukan penyetoran, yaitu:

Hutang PPh Pasal 4 Ayat (2) 7.612.639,90

Kas/Bank

$7.612 .639,90$

Dalam proses penyetoran pajak PPh pasal 4 ayat (2) AP staff menerima invoice langsung yang diberikan oleh pihak mall, $A P$ staff akan memberikan nominal sewa yang harus dibayar ke bagian tax staff untuk dibuat faktur pajak atas pembayaran sewa berupa tanah dan bangunan. Bagian AP staff melakukan proses pembayaran sewa yang kemudian diberikan persetujuan oleh bagian supervisor dan dilakuikan pengecekan akhir apakah setuju untuk dibayar atau tidak, kemudian dikeluarkan oleh manager. Invoice diberikan ke bagian konsultan pajak untuk dibuat SPT. Berdasarkan peraturan pemerintah batas waktu pembayaran atas Pajak Penghasilan Pasal 4 ayat (2) pemotong yaitu tanggal 10 (sepuluh) bulan berikutnya setelah bulan pembayaran atau terutangnya sewa dan atas Pajak Penghasilan Pasal 4 ayat (2) setor sendiri yaitu 15 (lima belas) bulan berikutnya setelah bulan pembayaran atau terutangnya sewa. Dari hasil penelitian diketahui bahwa PT. ARP merupakan pihak yang memotong pajak sewa maka batas waktu penyetoran atas sewa tanah dan bangunan yang dilakukan PT. ARP yaitu tanggal 10 (sepuluh) dari bulan berikutnya setelah masa pajak berakhir.

\section{Pelaporan Pajak}

Pelaporan pajak yang diteliti adalah proses pelaporan $\mathrm{PB} 1$ dan proses pelaporan $\mathrm{PPh}$ pasal 4 ayat (2) yang dilakukan oleh perusahaan PT. ARP berdasarkan dokumendokumen yang diproleh dari perusahaan tersebut untuk diteliti sebagai berikut.

Proses Pelaporan PB1 - Setelah menghitungan dan menyetor pajak, perusahaan kemudian melaporkan ke pihak pajak serta menyimpan bukti bayar yang telah dilunasi. Setelah pembayaran dilunasi website pemda akan otomatis mengklaim bukti pajak tersebut. Kendala yang dialami dalam proses pelaporan pajak PB1 adalah lema bayar periode sebelumnya. PT. ARP melakukan pelaporan pajak PB1 pada tanggal 15 (lima belas), apabila terdapat pajak yang tidak dilaporkan maka akan dikenakan sanksi pajak sebesar $2 \%$ (dua persen) perbulan bagi pajak yang tidak pernah dibayarkan. Jika wajib pajak telat melapor maka akan dikenakan sanksi berupa denda sebesar 25\% (dua puluh lima persen) dari pokok pajak ditambah dengan sanksi administrasi berupa bunga sebesar $2 \%$ (dua persen) sebulan, dihitung dari pajak yang kurang atau terlambat dibayar untuk 
Tax Treatment, Registration and Reporting

260 jangka waktu paling lambat 24 (dua puluh empat) bulan dihitung sejak saat terutang pajak. PT. ARP diketahui memperoleh surat teguran sebanyak empat surat teguran yaitu pada tanggal 16 Juli 2019 dengan denda sebesar Rp Rp 1.303.162 untuk tunggakan pajak bulan Mei 2019, 18 November 2019 dengan denda sebesar RP 6.497.825 untuk tunggakan pajak bulan Mei 2019, 17 Desember 2019 dikarenakan perusahaan belum menyampaikan surat SPTPD restoran untuk masa pajak November 2019, dan 25 September 2019 atas tunggakan pajak restoran untuk masa pajak Februari 2019 sampai Agustus 2019 untuk outlet Cibinong.

Proses Pelaporan PPh Pasal 4 Ayat (2) - Pelaksanaan kewajiban Pajak Penghasilan Pasal 4 ayat (2) Pada PT. ARP atas penghasilan berupa sewa tanah dan/bangunan besarnya $\mathrm{PPh}$ yang dipotong adalah sebesar $10 \%$ baik atas penghasilan yang diterima oleh wajib pajak badan maupun orang pribadi dari jumlah bruto nilai persewaan tanah dan/atau bangunan. Dalam pelaporan pajak badan bulanan SPT Masa PPh Pasal 4 ayat (2), sehubungan dengan pajak yang dipotong dari penghasilan yang dipotong dari bunga deposito dan tabungan lainnya, bunga obligasi dan surat utang negara, bunga simpanan yang dibayarkan koperasi, hadiah undian, transaksi saham dan sekuritas lainnya, serta transaksi lain sebagaimana diatur dalam peraturannya. Batas waktu pembayaran jatuh pada tanggal 10 (sepuluh) bulan berikutnya, diikuti tanggal 20 (dua puluh) dimana merupakan batas waktu pelaporan.

PT. ARP telah melaksanakan perhitungan, penyetoran dan pelaporan yang telah ditetapkan oleh peraturan pajak yang berlaku tidak terdapat kendala dalam proses pelaporan pajak PPh pasal 4 ayat (2). Namun dalam pelaksanaan pembayaran sewa, PT. ARP cenderung menunda pembayaran hingga batas jatuh tempo yang ditetapkan. Hal itu dapat diketahui berdasarkan hasil yang dilakukan peneliti, peneliti menemukan beberapa surat teguran sewa yang diberikan untuk PT. ARP. Dikarenakan penundaan pemayaran tersebut mengakibatkan menumpuknya utang pajak. Untuk pajak yang tidak pernah dibayarkan akan dikenakan sanksi setiap bulannya sebesar $2 \%$ (dua persen). Pembayaran pajak atas sewa tanah dan/atau bangunan melaui pemotongan dan pemenungutan oleh pihak lain PPh pasal 4 ayat (2). Pihak lain yang dimaksud adalah pemberi penghasilan, pemberi kerja, dan pihak lain yang ditunjuk atau ditetapkan oleh pemerintah. Pelaksanaan pembayaran pajak dapat dilakukan di kantor penerimaan pembayaran dengan menggunakan Surat Setoran Pajak (SSP) yang dapat diambil di Kantor Pelayanan Pajak (KPP) atau melalui pembayaran pajak secara elektronik (epayment). Surat Setoran Pajak adalah bukti pembayaran atau penyetoran pajak yang telah dilakukan dengan menggunakan formulir atau dengan cara lain ke kas negara melalui tempat pembayaran yang ditunjuk oleh Menteri Keuangan.

Formulir dalam Surat Setoran Pajak dibuat dalam rangkap 4 (empat), dengan peruntukan sebagai berikut:

a. Lembar ke-1: Untuk arsip Wajib Pajak

b. Lembar ke-2: Untuk Kantor Pelayanan Perbendaharaan Negara (KPPN)

c. Lembar ke-3: Untuk dilaporkan Wajib Pajak ke Kantor Pelayanan Pajak

d. Lembar ke-4: Untuk arsip kantor penerima pembayaran

Surat Setoran Pajak (SSP) dapat dibuat dalam rangkap 5 (lima) dengan peruntukan lembar ke-5 untuk arsip Wajib Pungut atau pihak lain sesuai dengan ketentuan perpajakan yang berlaku. Sebagai bukti bahwa Pajak Penghasilan Pasal 4 ayat (2) atas sewa bangunan telah dipotong, pihak pemotong harus memberikan bukti potong (rangkap ke-1) yang sudah dilengkapi dan diberikan kepada pihak yang dikenakan pajak dan bukti potong (rangkap ke-2) pada saat melakukan e-filling di website pajak.

Pencatatan biaya PPh Pasal 4 ayat (2) atas biaya sewa dilakukan pembayaran atas invoice dan hutang yang dimiliki PT. ARP yang dilakukan oleh bagian AP staff yang bertanggung jawab atas semua pengeluaran biaya perusahaan. Perusahaan akan membuat kontrak penyewaan bangunan dengan vendor atau pemilik bangunan. Batas waktu pelaporan yang ditetapkan oleh peraturan pemerintah yaitu 20 (dua puluh) hari setelah masa pajak berakhir. PT. ARP melakukan pelaporan pajak penghasilan pasal 4 
ayat (2) yaitu pada tanggal 15 (lima belas) dari bulan berikutnya setelah masa pajak berakhir.

\section{Pembahasan}

PT. ARP adalah suatu perusahaan yang bergerak dibidang food and beverages yang didirikan pada tanggal 10 April tahun 2013. Penelitian ini menggunakan data laporan penjualan yang dikenakan pajak PB1 dan data sewa bangunan yang dikenakan Pajak Penghasilan Pasal 4 ayat (2) karena data tersebut dinilai cukup mempresentasikan kondisi perusahaan PT. ARP saat ini. Dalam penelitian ini peneliti menggunakan data primer. Teknik pengumpulan data yang digunakan peneliti adalah penelitian lapangan, pengamatan (observasi), data dari objek, data fisik proleh berdsarkan data dari objek, seperti data fisik berupa bukti catatan, laporan historis perusahaan, dan dokumen perusahaan.

Berdasarkan hasil penelitian yang dilakukan pada perusahaan PT. ARP diketahui dalam proses perlakukan pajak restoran PB1, perusahaan PT. ARP telah menjalankan kewajibannya sebagai wajib pajak sesuai dengan perturan pajak yang berlaku, namun dapat diketahui dari seluruh total penjualan yang diperoleh PT. ARP peneliti menemukan bahwa tidak sepenuhnya total penjualan perusahaan dihitung, disetor dan dilaporkan sebagai pemotong PB1 oleh PT. ARP, akan tetapi perusahaan menghindari pembayaran pajak dikarenakan untuk membayar seluruh kebutuhan yang diperlukan perusahaan.

Dalam proses pencatatan perusahaan PT. ARP kurang memperhatikan dalam proses pencatatan penjurnalan karena perusahaan hanya berfokus kepada data rekapan omset penjualan. Untuk proses penyetoran bila dibandingkan dengan peraturan perpajakan yang berlaku, perusahaan telah menjalankan proses penyetoran pajak berdasarkan hasil rekapan penjualan yang telah dihitung oleh perusahaan. Dalam proses perhitungan dan pencatatan yang akan disetorkan diketahui pada suatu bulan penjualan PT. ARP yang dibayar dan dilaporkan sebesar Rp 628.122.920 dari hasil total penjualan ditambah dengan pajak PB1 yang dikenakan sebesar Rp 57.102.084 sedangkan berdasarkan data penjulanan yang diperoleh perusahaan dibulan tersebut sebesar $\mathrm{Rp} 756.010 .879$, seharusnya pajak PB1 yang dikenakan oleh perusahaan dikenakan sebesar 68.728.261. berdasarkan hasil perbandingan tersebut dapat diketahui bahwa perusahaan tidak sepenuhnya melaporkan hasil penjualannya kepada Badan Pendapatan Daerah.

Dalam proses pelaporan, perusahaan telah menjalankan proses pelaporan pajak sesuai dengan rangkaian yang ditetapkan oleh peraturan perpajakan, namun masih ditemukan sistem perpajakan yang tidak ada atau bermasalah sehingga pelaporan pajak tersebut tidak dilaksanakan. Badan Pendapatan Daerah akan mencurigai perusahaan yang mencoba untuk menghindari pajak, apabila perusahaan terbukti melakukan kecurangan maka akan dikenakan sanksi pajak sebesar $2 \%$ (dua persen) perbulan bagi pajak yang tidak pernah dibayarkan. Sistem pemungutan pajak PB1 adalah self assessment system merupakan suatu sistem pemungutan pajak yang memberi wewnang kepada wajib pajak untuk menentukan sendiri besarnya pajak yang terutang.

Hasil wawancara yang dilakukan menyatakan bahwa PT ARP berencana untuk melaporkan seluruh omset pajak dimasa yang akan datang dalam kurun waktu yang belum dapat ditentukan. Berdasarkan penelitian yang dilakukan, untuk membantu perusahaan dalam mengatasi permasalahan omset yang belum dibayarkan, perhitungan yang dilakukan perusahaan adalah menghitung sisa dari omset yang belum disetor dan dilaporkan, yaitu 2\% (dua persen) dikalikan dengan seluruh omset yang belum dibayar.

Sedangkan dalam perlakuan Pajak Penghasilan Pasal 4 ayat (2) diketahui perusahaan cenderung untuk memperlambat pembayaran sewa atas tanah dan bangunan dan lebih mengutamakan untuk pembayaran bahan pokok penjualan. PT. ARP merupakan sebagai pemotong pajak sewa, oleh karena itu perhitungan yang harus dilakukan oleh PT. ARP dalam suatu bulan adalah Harga sewa Rp 83.739.039 dikalikan dengan dasar pengenaan pajak, kemudian total dasar pengenaan pajak dikalikan dengan $10 \%$ (sepuluh persen) berdasarkan tarif pajak sewa atas tanah dan bangunan. Sehingga jumlah setor PPh Pasal 4 ayat (2) yang dipotong oleh perusahaan sebesar Rp 7.612.639,90.
Tax Treatment, Registration and Reporting 
Tax Treatment, Registration and Reporting

\section{2}

Dalam proses pencatatan perusahaan kurang memperhatikan pencatatan penjurnalan dan lebih mengutamkan data dari rekapan biaya sewa berupa invoice yang dikirim oleh pihak pemberi sewa serta faktur pajak. Untuk proses penyetorannya perusahaan PT. ARP cenderung membayar sewa melebihi batas jatuh tempo yang telah ditetapkan sehingga berdampak bagi penyetoran dan pelaporan pajaknya. Hal tersebut tidak sesuai dengan peraturan perpajakan yang berlaku karena dalam batas waktu penyetoran pajak penghasilan pasal 4 ayat (2) bagi pemotong yaitu tanggal 10 dari bulan berikutnya setelah masa pajak berakhir dan batas waktu pelaporan untuk pajak penghasilan pasal 4 ayat (2) yaitu 20 hari setelah masa pajak berakhir.

Apabila perusahaan terlambat dalam membayar pajak $\mathrm{PPh}$ pasal 4 ayat (2) perusahaan akan dikenakan denda sebesar $2 \%$ (dua persen) perbulan dari jumlah pajak terutang dihitung mulai dari tanggal jatuh tempo pembayaran sampai dengan tanggal pembayaran. Sistem pemungutan pajak PPh Pasal 4 ayat (2) adalah withholding system merupakan suatu pemungutan pajak yang memberi wewenang kepada pihak ketiga untuk memotong atau memungut besarnya pajak yang terutang oleh wajib pajak.

Prosedur pembayaran denda pajak yang dapat dilakukan oleh perusahaan adalah Wajib Pajak harus mendapatkan Surat Tagihan Pajak (STP) terlebih dahulu. STP terdiri dari lembar dokumen yang berisi besaran tagihan denda yang harus dibayarkan atas kelalaian wajib pajak dalam laporan SPT. Kemudian jika sudah mendapatkan STP dan mempersiapkan besaran denda yang harus dibayarkan maka perusahaan dapat membayar denda telat lapor SPT ke bank atau kantor pos.

Pelunasan pajak penghasilan atas persewaan tanah dan bangunan, pemotongan oleh penyewa dalam hal penyewa adalah Badan Pemerintah, Subjek Pajak badan dalam negeri, penyelenggara kegiatan, bentuk usaha tetap, kerjasama operasi, perwakilan perusahaan luar negeri lainnya, dan orang pribadi yang ditetapkan oleh Direktur Jenderal Pajak.

\section{PENUTUP}

Berdasarkan hasil penelitian yang telah dilakukan oleh peneliti terhadap PT. ARP untuk pajak PB1 peneliti dapat menarik kesimpulan, yaitu dalam proses perlakuan pajaknya perusahaan telah menghitung $\mathrm{PB} 1$ setiap bualnnya, namun diketahui bahwa jumlah penjualan yang dihitung untuk disetorkan kepada Badan Pendapatan Daerah tidak sesuai dengan jumlah penjualan yang sebenarnya. Perusahaan melakukan tindakan untuk mengecilkan jumlah pajak terutang, pemilik restoran tidak trasparan dalam pelaporan pajak yang seharusnya dibayarkan. Dalam proses pencatatan PB1 PT. ARP kurang memperhatikan dalam proses pencatatan penjurnalan karena perusahaan hanya mengutamakan data rekapan omset penjualan. Untuk mengembangkan kemajuan perusahaan, perusahaan mengatakan akan memperbaiki kesalahan yang dilalukan. Dalam proses pelaporan PB1 ditemukan bahwa sebagian dari omset penjualan tidak dilapokan kepada Badan Pendapatan Daerah, serta terdapat beberapa outlet yang tidak dilaporkan oleh perusahaan dikarenakan untuk pajak diwilayah tertentu belum terdapat sistem perpajakannya, selain itu perusahaan berupaya menghindari pajak untuk memenuhi kebutuhan perusahaannya sehingga perusahaan memiliki utang pajak atas penjualan yang tidak dilaporkan oleh perusahaan. Tidak semua sistem perpajakan yang dilakukan secara elektronik, melainkan diketahui bahwa terdapat beberapa wilayah yang proses pelaporannya langsung dilakukan di pajak daerah dan tidak memiliki sistem. Dalam proses penelitian ditemukan bahwa PT. ARP memperoleh beberapa surat teguran yang dikirimkan oleh Dinas Badan Pengelolaan Pendapatan Daerah karena telat melapor pajak.

Sedangkan hasil penelitian yang telah dilakukan oleh peneliti dalam proses perlakuan PPh Pasal 4 ayat (2), PT. ARP telah melaksanakan kewajiban atas perhitungan PPh Pasal 4 ayat (2) yang dikenakan dari kegiatan menyewa sebuah bangunan untuk dijadikan sebagai tempat kegiatan usahanya dan PT. ARP sebagai pemotong pajak juga telah memberikan bukti potong kepada pemberi sewa. Dalam proses pencatatan $\mathrm{PPh}$ Pasal 4 ayat (2), PT. ARP kurang memperhatikan pencatatan penjurnalan dan lebih 
mengutamakan data dari rekapan biaya sewa berupa invoice yang dikirim oleh pihak pemberi sewa serta faktur pajak. PT. ARP mengalami kendala dalam rincian invoice pembayaran sewa dikarenakan untuk tahun-tahun sebelumnya terjadi kehilangan data dan pencatatan pembayaran dalam perusahaan tersebut tidak sepenuhnya terinput, hal tersebut sangat disayangkan karena perusahaan dapat mengalami kesulitan apabila perusahaan terjadi pengecekan oleh kantor pajak ataupun pihak pemilik sewa yang ingin meminta bukti pembayaran yang dilakukan oleh perusahaan. Perusahaan kurang memperhatikan dalam pengarsipan dokumen penting, terutama dalam surat berupa tagihan pembayaran ataupun surat teguran. Dalam proses pelaporan $\mathrm{PPh}$ Pasal 4 ayat (2), pelaporan yang dilakukan oleh perusahaan sesuai dengan proses pelaporan yang berlaku, akan tetapi dalam pembayaran sewa tersebut perusahaan cenderung menunda pembayaran hingga melebihi batas jatuh tempo pembayaran. Sehingga berdampak pada proses pelaporan pajaknya.

Dalam menjalankan kegiatan usahanya, PT. ARP telah memenuhi kewajiban perpajakan atas Pajak PB1 dan Penghasilan Pasal 4 ayat (2). PT. ARP sebagai wajib pajak telah memiliki NPWP dan NPWPD, dan memiliki laporan keuangan atas kegiatan usahanya. Namun dalam prakteknya PT. ARP berupaya untuk mengurangi pembayaran PB1. Perusahaan merencanakan untuk kedepannya akan mencatat dan menyetorkan seluruh omset penjualan kepada Badan Pendapatan Daerah sesuai dengan peraturan perpajakan yang berlaku, tetapi masih dalam kurun waktu yang belum dapat ditentukan. Dalam pembayaran PPh Pasal 4 ayat (2) PT. ARP cenderung menunda pembayaran sewa dan telat untuk memberikan bukti potong kepada pemberi sewa.

\section{DAFTAR PUSTAKA}

Aditya, P.2015. Pengaruh Sanksi Perpajakan, Kualitas Pelayanan dan Kewajiban Moral pada Kepatuhan Wajib Pajak. E-Jurnal Akuntansi Universitas Udayana Vol 10.2.

Agoes, Sukrisno, Estralita Trisnawati.2013. Akuntansi Perpajakan. Edisi 3, Salemba Empat, Jakarta.

Badan Pusat Statistik. Presentase Konstribusi Pajak. [Internet]. [Diakses pada tanggal 13 Februari 2020]. Tersedia pada: https://www.bps.go.id.

Bagas, Rifki.2019. Kontribusi Pajak. Pegawai Direktorat Jenderal Pajak. [Internet]. [Diakses pada tanggal 13 Februari 2020]. Tersedia pada: https://www.pajak.go.id.

Bagus, Ida.2016. Pengaruh Kesadaran, Kualitas Pelayanan, Pemeriksaan dan Sanksi Perpajakan pada Kepatuhan Wajib Pajak Restoran. E-Jurnal Akuntansi Universitas Udayana Vol.16.2.

Direktorat Jendral Pajak.2020. Batas Waktu Pembayaran Penyetoran dan Pelaporan Pajak. [Internet]. [Diakses pada tanggal 1 Juli 2020]. Tersedia pada: https://www.pajak.go.id.

Direktorat Jendral Pajak.2020. Pengurangan dan Penghapusan Sanksi Administrasi. [Internet]. [Diakses pada tanggal 1 Juli 2020]. Tersedia pada: https://www.pajak.go.id.

Direktorat Jendral Pajak.2020. Pajak Penghasilan Pasal 4 ayat (2). [Internet]. [Diakses pada tanggal 12 Februari 2020]. Tersedia pada: https://www.pajak.go.id.

Hana, S.2017. Pengaruh Modernisasi Sistem Pajak. Akuntansi FE UMP.

Hari Advianto S. 2014. Pemotongan dan Pemungutan Pajak Penghasilan. [Internet].

[Diakses pada tanggal 13 Februari 2020]. Tersedia pada http://www.bppk.kemenkeu.go.id.

Ita, R.2015. Pengaruh Kualitas Pelayanan Pajak. Fakultas Ekonomi UMP.

Kementrian Keuangan Direktorat Jendral Perimbangan Keuangan.2020. Mekanisme Pengurangan dan Penghapusan Sanksi Administratif Serta Pengurangan Pokok Ketetapan Pajak. [Internet]. [Diakses pada tanggal 1 Juli 2020]. Tersedia pada: https://www. djpk.kemenkeu.go.id.

Mardiasmo.2013. Perpajakan. Edisi Revisi, Andi, Yogyakarta.
Tax Treatment,

Registration and Reporting 
Tax Treatment, Registration and Reporting

264
Masruroh, Siti., dan Zulaikha.2013. Pengaruh Kemanfaatan NPWP, Pemahaman Wajib Pajak, Kualitas Pelayanan, Sanksi Perpajakan Terhadap Kepatuhan Wajib Pajak. Diponegoro Journal Of Accounting ISSN 2337-3806 Volume 2 No 4 (2013): 1-15.

Maulidia, Rani.2018. Pajak Restoran: PPN atau Pajak Daerah. PT Achiles Advanced. [Internet]. [Diakses pada tanggal 12 Februari 2020]. Tersedia pada: https://www.online-pajak.com/pajak-restoran.

Mirta Pajak Resmi.2019. Pajak Restoran. PT MID. [Internet]. [Diakses pada tanggal 13 Februari 2020]. Tersedia pada: https://klikpajak.id.

Mrinawati, M.2015. Kepatuhan Wajib Pajak. UIN Malang. [Internet]. [Diakses pada tanggal 15 Februari 2020]. Tersedia pada: http://etheses.uin-malang.ac.id.

Mudiaga, A and Olusola, I.2019. E-Journal: Electronic Taxation and Tax Compliance Among Some Selected Fast Food Restaurants in Lagos State, Nigeria (Tax Payers Prespective).

Muljono, Djoko.2012. Pengaruh Perpajakan pada penerapan Standar Akuntansi Keuangan Entitas Tanpa Akuntanbilitas Publik, Andi, Yogyakarta.

Mulyana, Dedy.2013. Metodologi Penelitian Kualitatif, PT Remaja Rosdakarya, Bandung.

Pajak Penghasilan Pasal 4 ayat (2).2015. [Internet]. [Diakses pada tanggal 12 Februari 2020]. Tersedia pada: http://www.klinikpajak.co.id.

Pelaporan dan Pembayaran Pajak. [Internet]. [Diakses pada tanggal 13 Februari 2020]. Tersedia pada: http://www.pajak.go.id.

Pemotong Pajak Penghasilan Pasal 4 ayat (2). [Internet]. [Direktorat Jendral Pajak diakses pada tanggal 12 Februari 2020]. Tersedia pada: http://www.pajak.go.id.

Pengertian Pajak Final. [Internet]. [Diakses pada tanggal 12 Februari 2020]. Tersedia pada: https://www.online-pajak.com.

PERDA Bekasi, BAPENDA Bekasi kota.2018. Pajak Restoran. [Internet]. [Diakses pada tanggal 14 Februari 2020]. Tersedia pada: http://bapenda.bekasikota.go.id.

PERDA Bogor.2012. Pajak Restoran. [Internet]. [Diakses pada tanggal 14 Februari 2020]. Tersedia pada: https://kotabogor.go.id.

PERDA DKI Jakarta, BPRD provinsi DKI Jakarta.2011. Pajak Restoran. [Internet]. [Diakses pada tanggal 14 Februari 2020]. Tersedia pada: https://bprd.jakarta.go.id.

PERDA Kabupaten Bandung.2010. Pajak Restoran. [Internet]. [Diakses pada tanggal 14 Februari 2020]. Tersedia pada: http://jdih.bandungkab.go.id.

Pratiwi, Inten.2016. Pengaruh Kualitas Pelayanan, Pemeriksaan Pajak Pengetahuan Perpajakan dan Sanksi Perpajakan pada Kepetuhan Wajib Pajak Restoran. E-Jurnal Akuntansi Universitas Udayana Vol.16.2.

Primandita, Fitriandi, Yuda Aryanto, Agus P. Priyono.2014. Kompilasi undangundang Perpajakan Terlengkap, Salemba Empat, Jakarta.

PT Achiles Advanced.2016. Cara Bayar Pajak Online. [Internet]. [Diakses pada tanggal 12 Februari 2020]. Tersedia pada: https://www.online-pajak.com.

PT Achiles Advanced.2016. SPT Masa Pajak Penghasilan Pasal 4 ayat (2). [Internet]. [Diakses pada tanggal 1 Juli 2020]. Tersedia pada: https://www.online-pajak.com.

PT Fokus Solusi Proteksi.2016. Penghasilan yang Dikenakan PPh Pasal 4 ayat (2) dan Perhitungannya. [Internet]. diakses pada tanggal 13 Februari 2020. Tersedia pada: https://www.cermati.com.

Purwono, Herry.2010. Dasar-Dasar Perpajakan dan Akuntansi Pajak, Erlangga, Jakarta.

Putra, Nusa.2013. Metode Penelitian Kualitatif. Rajawali Pers, Jakarta.

Resmi, Siti.2014. Perpajakan Teori dan Kasus. Edisi 8, Salemba Empat, Jakarta.

Saad, Natrah.2014. E-Journal Tax Knowledge, Tax Comlexity and Tax Compliance: Taxpayers' View.

Sumarsan, Thomas.2015. Perpajakan Indonesia: Pedoman Perpajakan Lengkap Berdasarkan Undang-Undang Terbaru. Edisi 4, Indeks, Jakarta.

Waluyo.2011. Perpajakan Indonesia. Edisi 9. Buku 2, Salemba Empat, Jakarta.

Waluyo.2017. Perpajakan Indonesia. Edisi 12 Buku 1, Salemba Empat, Jakarta.

Wardoyo, Hadi, Teguh, Amin Subiyakto, Sapto W. Argo.2011. Pajak Terapan Brevet $A \& B$, TaxSys, Jakarta. 